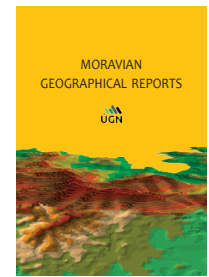

\title{
Barriers everyone: A new method for multiscale analysis of barriers using the Barrier Index
}

\author{
Domen KUŠAR ${ }^{a *}$, Blaž KOMAC ${ }^{b}$
}

\begin{abstract}
The Barrier Index is presented in this contribution. The index shows the extent to which spatial units of different sizes are closed off by barriers, influencing society by the different "thickness" and "thinness" of boundaries. The article defines the Index and compares land units with barriers in various details. The calculations were made for spatial units from the scale of parcels to one-hectare areas in selected types of regions, selected geographic regions, and border barriers in selected countries. The Index is useful for crossscale analysis and for identifying the underlying causes and relationships within different cultural, social, and geographical contexts. The example of spatially persistent family structures was used to highlight the underpinning influencing factors that connect the building of barriers at different scales.
\end{abstract}

Keywords: Barrier Index; border; barrier; fence; urban design; human geography

Article history: Received 5 September 2021, Accepted 22 November 2021, Published 31 December 2021

\section{Introduction}

A novel index that defines barriers as a spatial structure is proposed in this article. The term "barrier" is used in the sense of an umbrella term that refers to various physical barriers, such as fences and walls, security barriers, fortifications, and even virtual walls. It also refers to natural barriers. The novelty of this study is that it allows comparing barriers at different spatial scales and barriers in one place throughout history. In this way, the article contributes to a better understanding of the modern world, where barriers are increasing at all levels, especially at the level of countries that erect border barriers.

Barriers define the property of a place which is expressed as territoriality. Territoriality can be examined at different spatial scales: from primary (people's homes and places not accessible to others) to secondary (clubs and bars), to public (parks and streets), and to the national (country) level. The design of places is within the domain of architecture, whose criteria of strength, functionality, and beauty have been known since Antiquity (Vitruvius, 2009). However, a conflict arises in this regard: the more safety and privacy a specific place offers, the lower is its mobility. This separation is reflected in Robert Frost's poem, Mending Wall: "Good fences make good neighbours". At the local scale, the territory is defined as exclusive ownership of a portion of the earth's known surface, controlled by visually or physically permeable technical elements, such as walls and fences. This simple definition has evolved to bring a more complex understanding (Elden, 2013), including local and regional effects, and sovereignty as a legitimacy of social groups to exercise their power over territory (Domínguez-Mujica, DíazHernandez and Parreno-Castellano, 2016) and "to determine who belongs where and who is and who is not a member of the group" (Warf, 2010, p. 292). Introducing border barriers has long-term effects on society (Repe, 2018) - the border effect can be observed (Minondo, 2007).

The article addresses a research gap in the analysis of bordering at different spatial scales. We propose a method to analyse the relationships and possible differences between territories based on barriers at their borders. The analysis was done at the level of regions, countries, and cities (Jirón, 2010), as well as at lower spatial levels, such as parcels of land, typical examples of territories with defined ownership (Komac and Kušar, 2017; Revzina, 2018).

The main objective of the article is to define the Barrier Index and its subtypes, and to present its use in enclosed

\footnotetext{
${ }^{a}$ Faculty of Architecture, University of Ljubljana, Ljubljana, Slovenia (*corresponding author: D. Kušar, e-mail: domen.kusar@fa.uni-lj.si)

${ }^{\mathrm{b}}$ Anton Melik Geographical Institute, Research Centre of the Slovenian Academy of Sciences and Arts, Ljubljana, Slovenia
} 
areas of different sizes and types, from the level of parcel to the level of regions. In the Results section, a detailed analysis of the Barrier Index is carried out at the county level, for which comparable data are available. The new index allows physical barriers to be defined regardless of their relative size. Thus, we can present the underlying geographical processes, so that in the Discussion section we relate the barriers to some fairly stable social structures and propose some policy implications.

\section{Theoretical background}

The topic discussed here is clearly multidisciplinary as boundaries depend on a combined understanding of human relations, history, culture, economy, perceptions, stereotypes, ethics, symbols, and constructions (Pounds, 1972; Donnan and Wilson, 1999; Newman, 2003; Vallet, 2018). They are "real or understood, visible or invisible (Jones, 2012), natural or artificial, of legal or of no legal significance" (Clark, 1998, p. 50). Barriers are built at the borders to separate the interior from the exterior, the public from the private, the private from the private, and the private from the feudal, state-owned, and common (Petek and Urbanc, 2007) Providing privacy is a dynamic process, in which individuals or groups are controlled (Altman, 1977). Most of the research on the topic has been done at the level of countries.

As spatial border markers, barriers have accompanied the built environment since prehistory. The Bible describes how it is good for a vineyard to have "a wall to the right and a wall to the left" (Sir 36: 25; Num 22: 24). The nearly 10,000 km long discontinuous Great Wall of China was built through centuries after the $7^{\text {th }}$ century BC to prevent incursions of nomadic peoples from the Eurasian steppes, similar to the Japanese $20 \mathrm{~km}$ long Genkö Börui from the $13^{\text {th }}$ century. The Romans built several limites along their borders in the $2^{\text {nd }}$ century, while the Danish King Gudfred wall was built in the $7^{\text {th }}$ century. Although the idea of un-crossable lines disappeared with Ancient Rome, the barriers still enforce and justify the system of territorial borders (Vallet and David, 2012).

Nijkamp and Rietveld (1989) provided the first classification of barriers, dividing them into natural and manmade. An example of the former are mountainous areas, lakes, rivers, swamps (Alm and Burkhart, 2013), and seas, such as the Mediterranean (Locchi, 2016). In the early phases of territorialisation, physical delimitations became part of the cultural and political landscape, as shown by the following statement by Herder on the foundation of the US and Canada: "Nature separated nations by mountains, seas, rivers, and deserts" (cf. Pounds, 1972, p. 61)

At first, borders marked the territory of a specific people and, later the nation, and were ultimately defined as a feature of state territory. Before the development of nation-states, territories such as those in feudal Europe were delimited by fluid barriers, and by dynamic frontiers (Brown, 2010). From the Peace of Westphalia (1648) to the twentieth century, borders were conceived as linear landscape elements (Pounds, 1972). State borders evolved as lines of demarcation, marking the dissimilarities between institutional and cultural settings (Van Geenhuizen and Rietveld, 2002).

In the second half of the $20^{\text {th }}$ century, globalisation led to the opening of borders, increased mobility, and deterritorialisation (Sassen, 2008). Borders acquired the character of networks, and became more porous and loosely regulated (Dear, 2013). The term territory acquired a meaning that connects the contexts of terrain, identity, and culture (Agnew, 1994)

Nonetheless, territorial claims based on ethnic considerations have increased (Medzini, 2016). Various barriers have been erected, while the borders have been thickening and becoming less permeable due to security enhancements (Haselberger, 2014; Heiskanen, 2016). The process of bordering has created large frontiers or borderlands (Warf, 2010; Casey and Watkins, 2014). A reemphasis on statehood and demands for greater security (Newman, 2006; Warf, 2010) resulted in a shift from borders and fences to walls (Jones, 2012; Roche, 2016).

Border linearity is now being emphasised again, but this time around it is enhanced with virtuality (Heyman, 2008) and dispersion (Kolossov, 2005) resulting in a "new border landscape" (Konrad, 2016, p. 90). Borders are increasingly marked by barriers and enhanced by social practices (Johnson, Jones, Paasi, Amoore, Mountz, Salter and Rumford, 2011), such as electronic biometric surveillance systems (Amsoore, 2006; Parker and VaughanWilliams, 2009; Golunov, 2014). As the new technologies may exist "everywhere" (Peńa, 2021) the borders became diffuse (Johnson et al., 2011). Dynamic border management works across scales, from the transnational level to the level of individuals, beyond border space (Adey, 2004; Newman, 2006; Heiskanen, 2016). We observe a trend of "examining and analysing issues beyond and below the scale of the nation-state" (Warf, 2010, p. 2224).

Paradoxically, the described border dispersion (Haselberger, 2014) is characterised by the development of thick borders with an increasing number of border separation barriers, fences, and walls (Wills, 2016). Even ordinary spaces are saturated with "borders, walls, fences, thresholds, signposted areas..." (Multiplicity, 2005). We face increasing local bordering activities (Silvey, Olson and Truelove, 2007) at increasingly lower spatial scales (Nijkamp and Rietveld, 1989), such as gated communities, "resilient" communities, and respect zones (Johnson et al., 2011). In this article we address this changing nature of border separation regardless of the spatial scale.

\section{Methods and data: Comparison of barriers at different spatial scales}

Spatial entities enclosed with boundaries that take the physical form of barriers are a general spatial feature. To analyse their meaning, each spatial unit, such as a parcel or state, must be ascribed a numerical value termed an index. The index shows the ratio between a barrier's length and the size, area, or other features of a selected entity.

As an index (as described by Wentz, 2000), the proposed Barrier Index is easy to understand, since similar phenomena have similar values, and the values are independent of the size of phenomena, their movements, and scale. The values are comparable across scales. We submit that the border barrier index can be a useful statistical measure, giving readings that vary widely between 0.00 and 1.00 or 0 and 100 (percent). This makes it possible to measure the status and tendencies within any given territory on one continuous scale.

Here we define the Barrier Index. To calculate the index for the selected spatial units we used the border barrier length and compared it to the land border length. Countries 
that, according to the data available, had built a wall or were located along a natural barrier were included. Data on border lengths, the area of countries, the population, and border barrier lengths were taken from publicly available sources, such as The World Factbook (2019).

The Barrier Index, originally based on the border barrier length, was further divided into four subtypes, with the option for additional ones. The Barrier Length Index (BLI) defines the share of an entity's perimeter in relation to the entire perimeter on which a barrier could be erected. It is expressed in absolute values as $\mathrm{m} / \mathrm{m}(\mathrm{km} / \mathrm{km})$ or in relative values as a percentage of a parcel's fenced perimeter. The values range between 0.00 and 1.00. The Barrier Area Index (BAI) is defined by the length of a fence per area of the spatial entity enclosed with this fence $\left(\mathrm{m} / \mathrm{m}^{2} ; \mathrm{km} / \mathrm{km}^{2}\right)$. For example, the length of border barriers of a country in $\mathrm{km}$ is divided by the area of the country in $\mathrm{km}^{2}$. For combined units (e.g. parts of settlements), this index can be calculated from the average indices of smaller units (e.g. parcels) that make up the larger one. The length of barriers in the spatial unit is summed and divided by the total area of the unit. To add a social perspective, the Barrier Population Index (BPI), is proposed. It is calculated by the value of the Barrier Length Index with the population (per 10,000 people) and it is thus population-density-dependent. As the borders are not just barriers but they allow mobility of people, goods, and data through openings, checkpoints, and gates (PallisterWilkins, 2016), we propose the Barrier Closure Index (BCI). It shows the ratio between length of the barrier (e.g. border in case of countries) in $1,000 \mathrm{~km}$ divided by the number of barrier openings or crossings (Fig. 1). In the case of country borders it is based on the number of land border crossings. Its values range from 0.00 to 1.00 . The low BCI defines barriers as "open" and high values as "closed".

\section{Results and discussion}

\subsection{Analysis at the parcel level}

Parcels are the smallest, precisely measured pieces of fertile or infertile land with one or several owners, belonging to a specific cadastral district, and entered in the land register under a specific number (Kladnik, Lovrenčak and Orožen Adamič, 2005). They vary in shape (Foški, 2019), land use, and size (Irwin and Bockstael, 2004). In this study, we present the example of parcels in various Slovenian regions.

We selected this example because the needed data were available (Geodetska..., 2020). The BLI for the selected parcels ranged between 0.50 and 1.00 , depending on the location of the main and auxiliary buildings in the parcel. Most parcels were quadrangular, with one side usually along the road where fences are most common. This is also confirmed by the BLI for roadside fences in selected towns across Slovenia, which ranged between 0.17 and 0.90 . The lowest value was recorded in Žerovnica, Southern Slovenia, where erecting fences is clearly not part of the local tradition and parcel borders are usually indicated with a curb, a road, or the edge of a lawn (Tab. 1).

\subsection{Analysis at the street level}

Certain differences of the BLI at the street level can be observed between the (Slovenian) regions, stemming from tradition and natural conditions. The Slovenian example was selected because its territory combines Alpine, Dinaric, Mediterranean and Pannonian landscapes and is a European landscape hotspot with high landscape diversity (Perko, Ciglič and Zorn, 2019). The calculated BLI ranges from 0.173 in the Dinaric region to 0.903 in the Pannonian region (Tab. 2). We observe that the differences are gradually disappearing due to globalisation. An example of this is the stone walls in karst regions, which were created because of piling up leftover rocks obtained by clearing farmland. Another example is the Ljubljana Marsh, where parcel borders are "marked" by ditches. Modern construction of parcel fences follows traditional patterns (Kušar and Komac, 2019).

\subsection{Analysis at the one-hectare area level}

One-hectare areas with detached houses in randomly selected examples of Cordoba (Argentina), Kampala (Uganda), Ljubljana (Slovenia), Nakhon Sawan (Thailand), and Uppsala (Sweden; Fig. 2) showed a BAI between 0.38 and 0.66. The index was the highest in Sweden (0.66) and

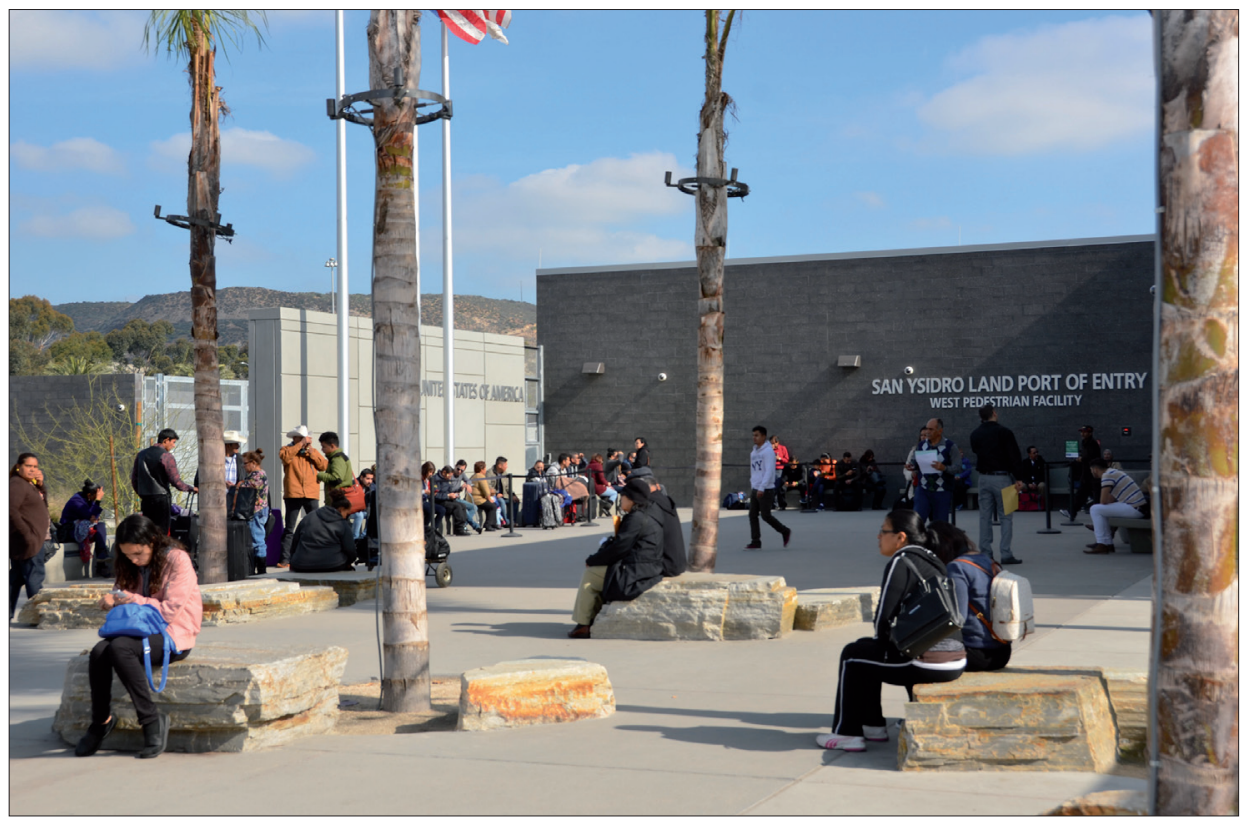

Fig. 1: The San Ysidro Port of Entry is the largest land border crossing between San Diego in the USA and Tijuana in Mexico. Source: Mimi Urbanc, with permission 


\begin{tabular}{|c|c|c|c|c|c|c|}
\hline Level & Unit name & $\begin{array}{c}\text { Number } \\
\text { of cadastral } \\
\text { municipality }\end{array}$ & $\begin{array}{l}\text { Number } \\
\text { of parcel }\end{array}$ & Coordinates & $\begin{array}{l}\text { Barrier Length } \\
\text { Index }\end{array}$ & $\begin{array}{l}\text { Barrier Area } \\
\text { Index }\end{array}$ \\
\hline 1 Parcel (Slovenia) & $\begin{array}{l}\text { Central } \\
\text { (Ivančna Gorica) }\end{array}$ & 1,820 & $46 / 1$ & $\begin{array}{l}45^{\circ} 56^{\prime} 19^{\prime \prime} \mathrm{N} \\
14^{\circ} 48^{\prime} 26^{\prime \prime} \mathrm{E}\end{array}$ & 1.00 & 145.83 \\
\hline 1 Parcel (Slovenia) & $\begin{array}{l}\text { Pannonian } \\
\text { (Nedelice) }\end{array}$ & 152 & 1414 & $\begin{array}{l}46^{\circ} 36^{\prime} 37^{\prime \prime N} \\
16^{\circ} 20^{\prime} 22^{\prime \prime} \mathrm{E}\end{array}$ & 0.54 & 53.99 \\
\hline 1 Parcel (Slovenia) & $\begin{array}{l}\text { Mediterranean } \\
\text { (Šmarje) }\end{array}$ & 2,608 & $889 / 1$ & $\begin{array}{l}45^{\circ} 30^{\prime} 07^{\prime \prime N} \\
13^{\circ} 42^{\prime} 54^{\prime \prime} \mathrm{E}\end{array}$ & 0.60 & 101.24 \\
\hline 1 Parcel (Slovenia) & Dinaric (Petelinje) & 2,501 & $1252 / 2$ & $\begin{array}{l}45^{\circ} 41^{\prime} 22^{\prime \prime} \mathrm{N} \\
14^{\circ} 11^{\prime} 43^{\prime \prime} \mathrm{E}\end{array}$ & 0.84 & 113.57 \\
\hline 1 Parcel (Slovenia) & Alpine (Kranj) & 2,131 & $128 / 1$ & $\begin{array}{l}46^{\circ} 13^{\prime} 54^{\prime \prime N} \\
14^{\circ} 20^{\prime} 29^{\prime \prime} \mathrm{E}\end{array}$ & 0.74 & 120.72 \\
\hline Average & & & & & 0.74 & 107.07 \\
\hline
\end{tabular}

Tab. 1: Barrier Index at the parcel level in selected Slovenian settlements Source: authors' calculations

\begin{tabular}{llcc}
\hline Level & Unit name & Coordinates & Barrier Length Index \\
\hline 2 Street (Slovenia) & Central (Ivančna Gorica) & $45^{\circ} 56^{\prime} 22 \mathrm{~N} ; 14^{\circ} 48^{\prime} 30^{\prime \prime} \mathrm{E}$ & 0.61 \\
2 Street (Slovenia) & Pannonian (Beltinci) & $46^{\circ} 36^{\prime} 32 \mathrm{~N} ; 16^{\circ} 13^{\prime} 31^{\prime \prime} \mathrm{E}$ & 0.90 \\
2 Street (Slovenia) & Mediterranean (Prade, Koper) & $45^{\circ} 32^{\prime} 19 \mathrm{~N} ; 13^{\circ} 46^{\prime} 29^{\prime \prime} \mathrm{E}$ & 0.59 \\
2 Street (Slovenia) & Dinaric (Žerovnica, Cerknica) & $45^{\circ} 45^{\prime} 31 \mathrm{~N} ; 14^{\circ} 25^{\prime} 33^{\prime \prime} \mathrm{E}$ & 0.17 \\
2 Street (Slovenia) & Alpine (Radovljica) & $46^{\circ} 20^{\prime} 57 \mathrm{~N} ; 14^{\circ} 10^{\prime} 16^{\prime \prime} \mathrm{E}$ & 0.70 \\
Average & & & $\mathbf{0 . 5 9}$ \\
\hline
\end{tabular}

Tab. 2: Barrier Index at the street level

Source: authors' calculations

the lowest in Thailand (0.38; Tab. 3). The aim was not to present a comprehensive analysis but to show that the method can be applied worldwide.

The analysis of four randomly chosen settlement areas around the world showed that the borders of land are marked everywhere, but that the types of barriers depend on a series of factors. In Sweden, the fences are low, made of wood or metal, and easy to traverse, but the border can also be indicated by ground landscaped in various ways

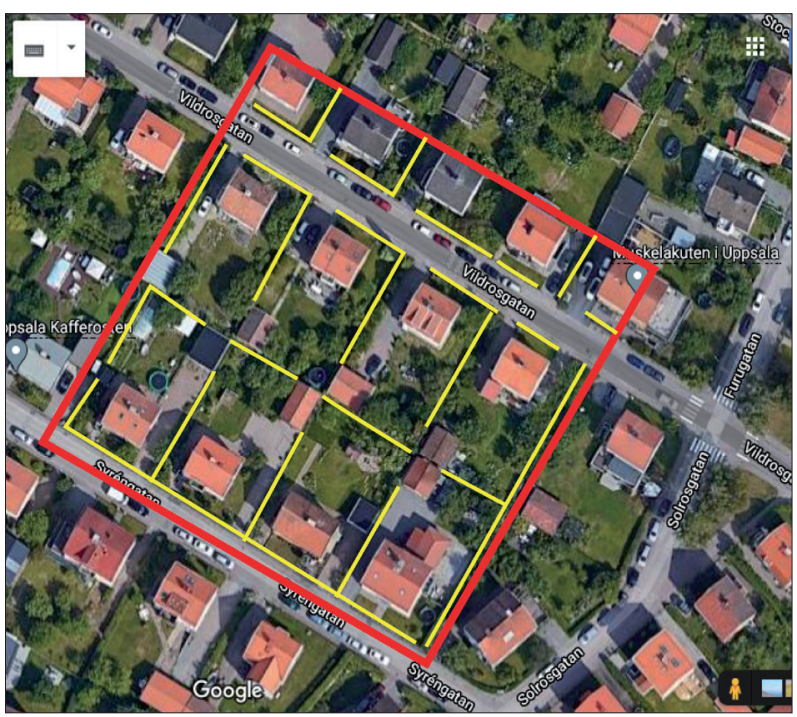

Fig. 2: Barrier Index for the one-hectare area in Uppsala (red: borders of the area examined, yellow: barriers) Source: Google Maps and Google Street View (gravel, grass, or flowerbeds). In Uganda, the fences are tall, furnished with security elements (barbed wire and broken glass), and are used to prevent access to land or for security reasons. Other examples (Cordoba, Ljubljana, and Nakhon Sawan) are somewhere in between. In Sweden and partly in Slovenia, the buildings mostly stand in the centre of parcels, whereas in Argentina and Uganda the main building is part of the border. Common and public land or low-value land usually has no fences.

In Europe, most cities removed their medieval walls at the end of the nineteenth century because, as military technology improved, the walls became ineffective and hindered urban expansion. They were replaced by other security devices and their security role moved to a higher, national level and to a lower, parcel level. Such abandonment of city walls shows that on the one hand cities were becoming more externally open and, on the other, more internally closed (Foucault, 2009), if referring to the fences and barriers around individual house lots.

\subsection{Analysis of countries}

Enclosing countries with barriers is a common practice in both totalitarian regimes and democracies (Fig. 3; Jones, 2012). As of 2013, "the US, Israel, Greece, Spain and India had a total of 6,000 kilometres of walls" (Vallet, 2018); see Vallet for a comprehensive overview. For this study, we collected data on erected barriers for the selected countries; border barriers with a total length of $10,659 \mathrm{~km}$ were covered (Tab. 4). This is a conservative estimate of built walls and fences as, according to some sources, the total length of border barriers around the world (not only walls and fences) varies from $18,000 \mathrm{~km}$ (Foucher, 2011) to more 


\begin{tabular}{llcc}
\hline Level & Unit name & Coordinates & Barrier Length Index \\
\hline 3 Settlement/Street & Ljubljana (Slovenia) & $46^{\circ} 02^{\prime} 22^{\prime \prime} \mathrm{N} ; 14^{\circ} 30^{\prime} 04^{\prime \prime} \mathrm{E}$ & 64.7 \\
3 Settlement/Street & Uppsala (Sweden) & $59^{\circ} 51^{\prime} 33^{\prime \prime} \mathrm{N} ; 17^{\circ} 39^{\prime} 33^{\prime \prime} \mathrm{E}$ & 66.0 \\
3 Settlement/Street & Cordoba (Argentina) & $31^{\circ} 25^{\prime} 20^{\prime \prime} \mathrm{S} ; 64^{\circ} 07^{\prime} 25^{\prime \prime} \mathrm{W}$ & 58.6 \\
3 Settlement/Street & Kampala (Uganda) & $0^{\circ} 22^{\prime} 49^{\prime \prime} \mathrm{N} ; 32^{\circ} 35^{\prime} 54^{\prime \prime} \mathrm{E}$ & 40.4 \\
3 Settlement/Street & Nakhon Sawan (Thailand) & $1^{\circ} 41^{\prime} 39^{\prime \prime} \mathrm{N} ; 100^{\circ} 06^{\prime} 52^{\prime \prime} \mathrm{E}$ & 38.0 \\
Average & & & $\mathbf{5 3 . 5 4}$ \\
\hline
\end{tabular}

Tab. 3: Barrier Index at the one-hectare area level Source: authors' calculations

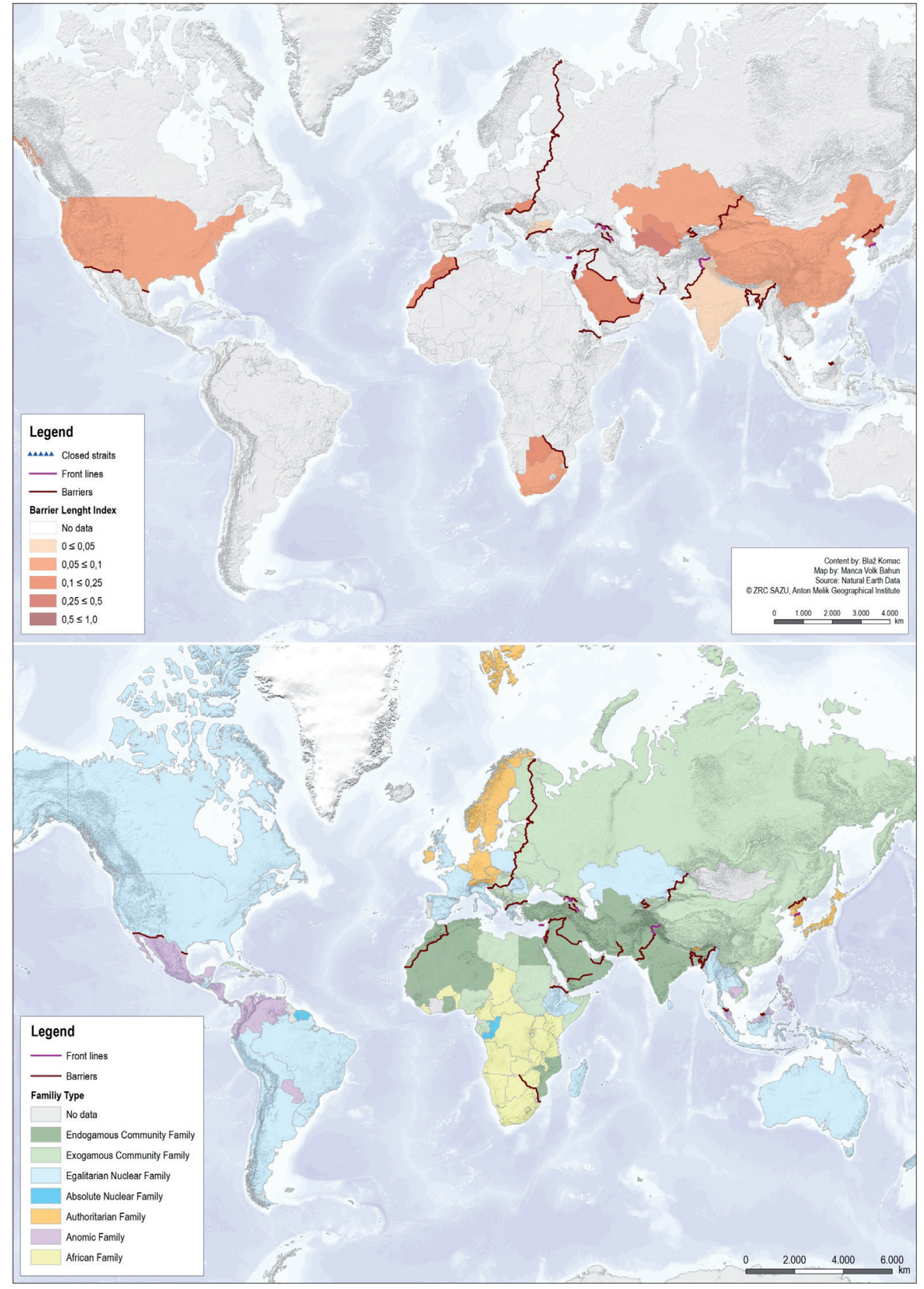

Fig. 3: Barrier Length Index in the countries with border barriers analysed (top) and the countries' predominant social structure illustrated by family systems (bottom)

Sources: Todd, 1985; data by Rijpma and Carmichael, 2016; Rosière and Jones, 2012: 219; Schengen included as a barrier; authors' compilation 


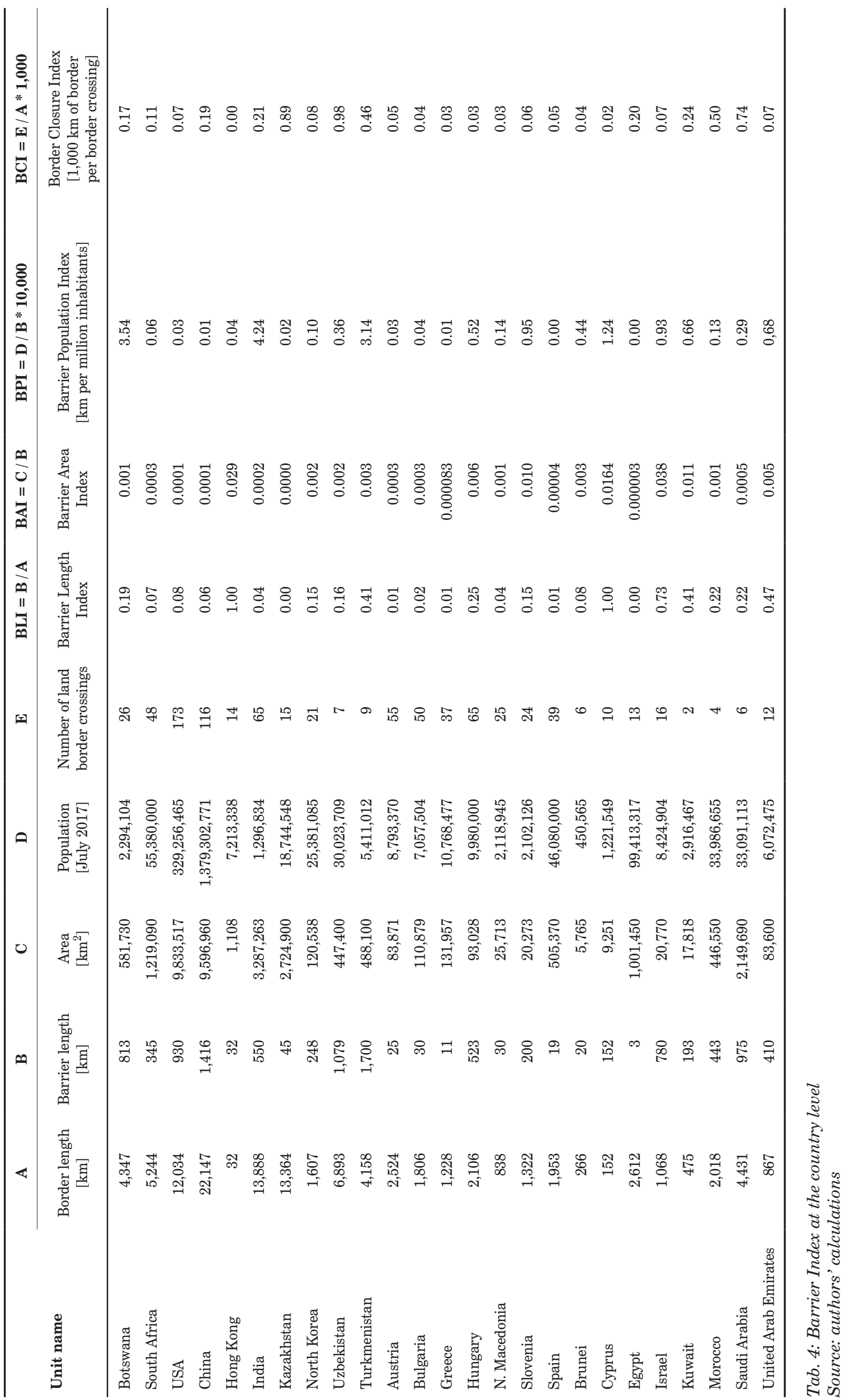


than 41,000 km of "terrestrial closed borders" (Ballif and Rosière 2009 , p. $193-206$ ), of which $87 \%$ or $35,670 \mathrm{~km}$ are walls and fences. According to Rosière and Jones (2012), the total length of border barriers is $27,624 \mathrm{~km}$, while the total length of forty-five walls was $29,000 \mathrm{~km}$ in 2011 according to Vallet (2018) and Vallet and David (2012). The data vary also because they may include the planned walls.

The mean BLI for the 25 analysed countries (Austria, Botswana, Brunei, Bulgaria, China, Cyprus, Egypt, Greece, Hong Kong, Hungary, India, Israel, Kazakhstan, Kuwait, Morocco, North Korea, North Macedonia, Uzbekistan, Saudi Arabia, Slovenia, South Africa, Spain, Turkmenistan, United Arab Emirates, and the USA) is 0.25 , with values ranging from 0.001 to 1.00 . The above-average values were recorded for Hong Kong and Cyprus (1.00), Israel (0.73), Kuwait (0.51), United Arab Emirates (0.47), Turkmenistan (0.41), and Hungary (0.25). The average BAI for the analysed countries with border barriers is 0.01 with a minimal value of 0.000003 for Egypt and a maximal value of 0.038 for Israel. The BPI ranges from 0.03 (Egypt) to 424.11 (India), with a mean value of 68.24 . The BCI ranges from zero (Hong Kong) to 0.98 (Uzbekistan), with a mean value of 0.21 .

Asia has the largest number of barriers among all the continents $(5,070 \mathrm{~km})$, with the Middle East having the highest average BLI (0.40; Fig. 4) and second highest BCI (0.23). As regards the BLI, the Middle East is followed by Asia (0.28) with the highest BCI (0.40). The BLI is low in Africa (0.13), North America (0.08), and Europe (0.07). The BPI is the highest in Asia and Africa (1.13 and 1.12, respectively) and the lowest in North America (0.03). In terms of barrier length, the Middle East is second $(2,976 \mathrm{~km})$, followed by North America $(930 \mathrm{~km})$, Africa $(845 \mathrm{~km})$, and Europe $(838 \mathrm{~km})$.

Calculating the BLI by country $(\mathrm{N}=25)$ made it possible to estimate the global index. All the world's countries combined have approximately $460,000 \mathrm{~km}$ of land borders and 10,659-29,000 km barriers. Hence, the global BLI is 0.02 to 0.06 . However, at the global level at least twice as many border barriers are planned or under construction (30 walls, 25,000 km long), following the increasing trend in the post-WWII-period (Vallet and David, 2012). Based on the US and Israel, the average cost of barrier building about $1.7 \times 10^{6} \mathrm{US} \$$ per $\mathrm{km}$ or $350,000 \mathrm{US} \$ / \mathrm{km} /$ year
(Vallet, 2018), the estimated global cost of building the barriers is $16 \times 10^{9} \mathrm{US} \$$, an equivalent to the GDP of Somalia, Haiti, Kosovo, South Sudan or Iceland.

\subsection{Analysis of the selected regions}

We present selected examples of the data on barriers for the Schengen Area (those borders that are subject to strict control), for Slovenia (Fig. 5) during various historical periods (Tab. 4), and some approximations for the selected historical and natural areas, such as China under the rule of the Ming Dynasty, the Alps, the Mississippi basin, and the continents.

The example of the Schengen Area covers four million square kilometres and is enclosed by a $6,277 \mathrm{~km}$ land border established in 1985, which, due to its strict controls, is here considered a border barrier (Haselberger, 2014). The BLI of this open area $(\mathrm{BCI}=0.04)$ is 0.68 , the $\mathrm{BAI}$ is 0.001 and the BPI 10.20. The BLI for historical China from the period of the Ming Dynasty - which ruled the country from the fourteenth to the seventeenth centuries (acknowledging the fact that the wall was continuously built through centuries after the $7^{\text {th }}$ century BC and did not function as a continuous barrier), when China was enclosed by a roughly $11,300 \mathrm{~km}$ long border and of which the Great Wall of China accounted for about $8,850 \mathrm{~km}$ - is estimated as high, at 0.78 (the BAI is 0.001 and the BPI 59.00). As concerns historical regions, we calculated the changes of BLI for Slovenia in order to present how a turbulent modern history influenced border barriers of a European country. Its territory belonged to the Austrian-Hungarian Empire before World War 1. After the war, the west belonged to Italy and a military line was built. Its territory was divided between Germany, Italy, Hungary, and Croatia during WWII by barriered borders. The BLI increased during the socialist regime (1945-1990) and decreased after Slovenia gained independence in 1991. By the introduction of the Schengen area, the BLI increased again and is expected to fall after Croatia joins the Schengen area (Fig. 6).

The Alps are an important natural barrier (Gams, 2001) that influences social, spatial, and political development. We considered the length and the area covered by the land borders of Austria, France, Italy, Germany, Slovenia, and Switzerland, and used the length of borders between Italy and the rest of these countries as an approximation. The

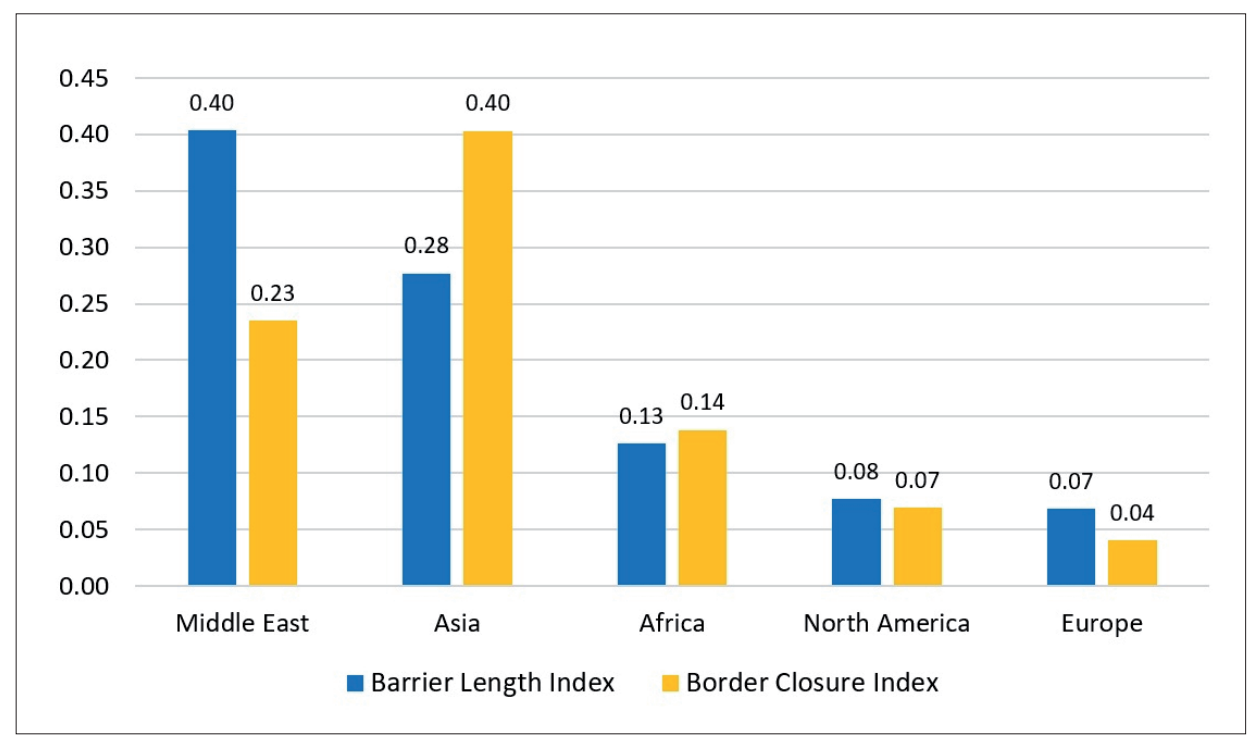

Fig. 4: The BLI and BCI by continents, based on the countries examined Source: authors' calculations 
BLI of the Alps is 0.22, the BAI 0.001, and BPI 133.00. With high number of mountain passes and some tunnels, the divide is rather an open one with the BCI at 0.15.

Large rivers, often form political borders (Pounds, 1972). We calculated the Barrier Index for the Mississippi, which separates the 2.5 million $\mathrm{km}^{2}$ western part (North Dakota, South Dakota, Nebraska, Kansas, Minnesota, Iowa, Missouri, Oklahoma, Texas, Arkansas, and Louisiana) from the 1.3 million $\mathrm{km}^{2}$ eastern part of the central US (Wisconsin, Michigan, Illinois, Indiana, Ohio, Kentucky, Tennessee, Missouri, and Alabama). The river is $3,778 \mathrm{~km}$ long, which is also the approximate length of the 'border' between the two areas. The BLI is 0.15 and 0.10 (east/ west), and the natural border is of a closed type (BCI $=0.18$ and 0.27). The method does not acknowledge the fact that the Mississippi River is not a meaningful political barrier as the state borders are completely open and that it can be easily crossed by many bridges and boat services.

\subsection{Physical barriers as a reflection of cultural contexts}

Closing borders at the level of parcels, settlements, and states is on the increase, and so is the trend of building border barriers and restricting mobility, even within uniform and closed territories, such as the European Union. At the same time, a distinction is being made between walls and more acceptable fences, which even leads to denial, such as that reported on along the Mexico - United States border (Vila, 2003, p. 217): "Mexican officials insisted that they were proposing not a border barrier fence but rather a train protection device."

The article presents a new method for interpreting barriers at different spatial levels. It proposes an indicator for analysing the closedness of borders that allows a temporal and spatial comparison of barriered borders regardless of their size. Some examples for each spatial level were presented.

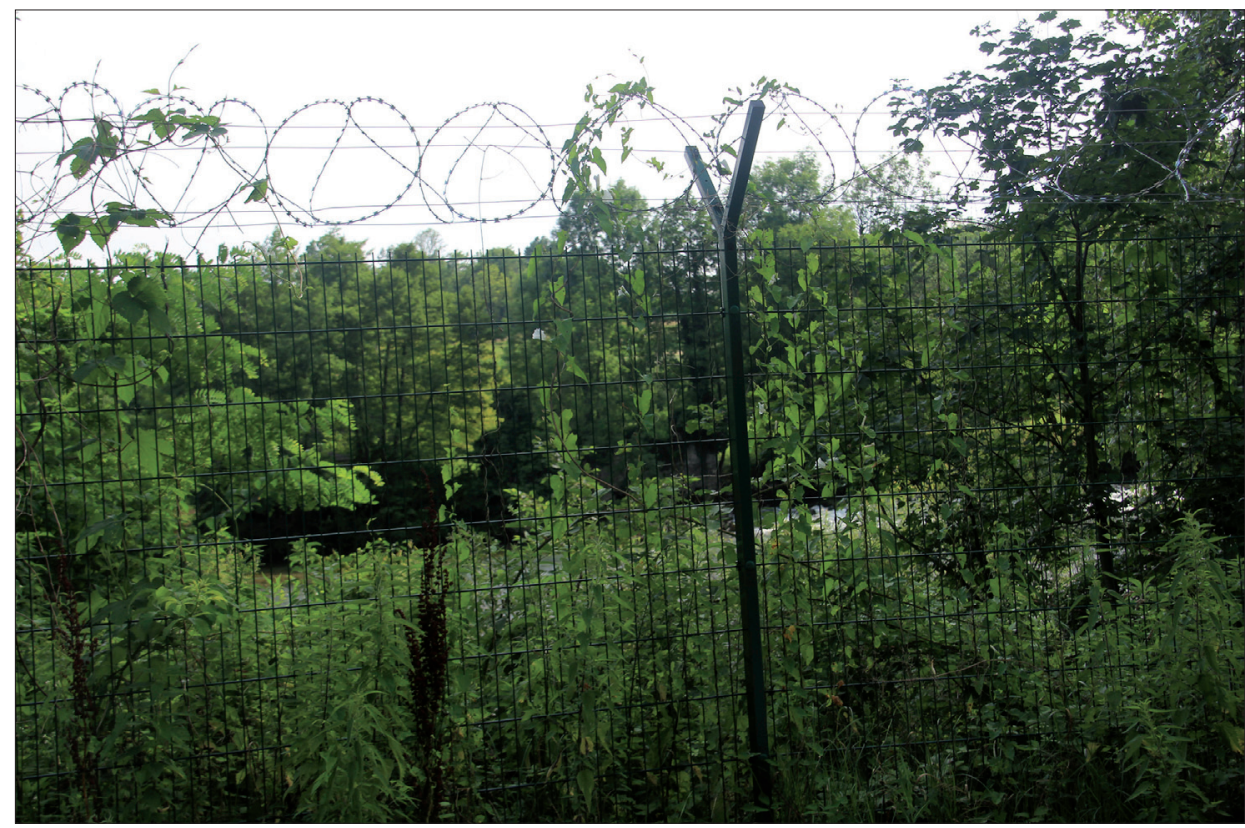

Fig. 5: The Slovenia-Croatia border barrier was erected near the Kolpa/Kupa River after the migrant crisis in 2015 Source: Matej Gabrovec, with permission

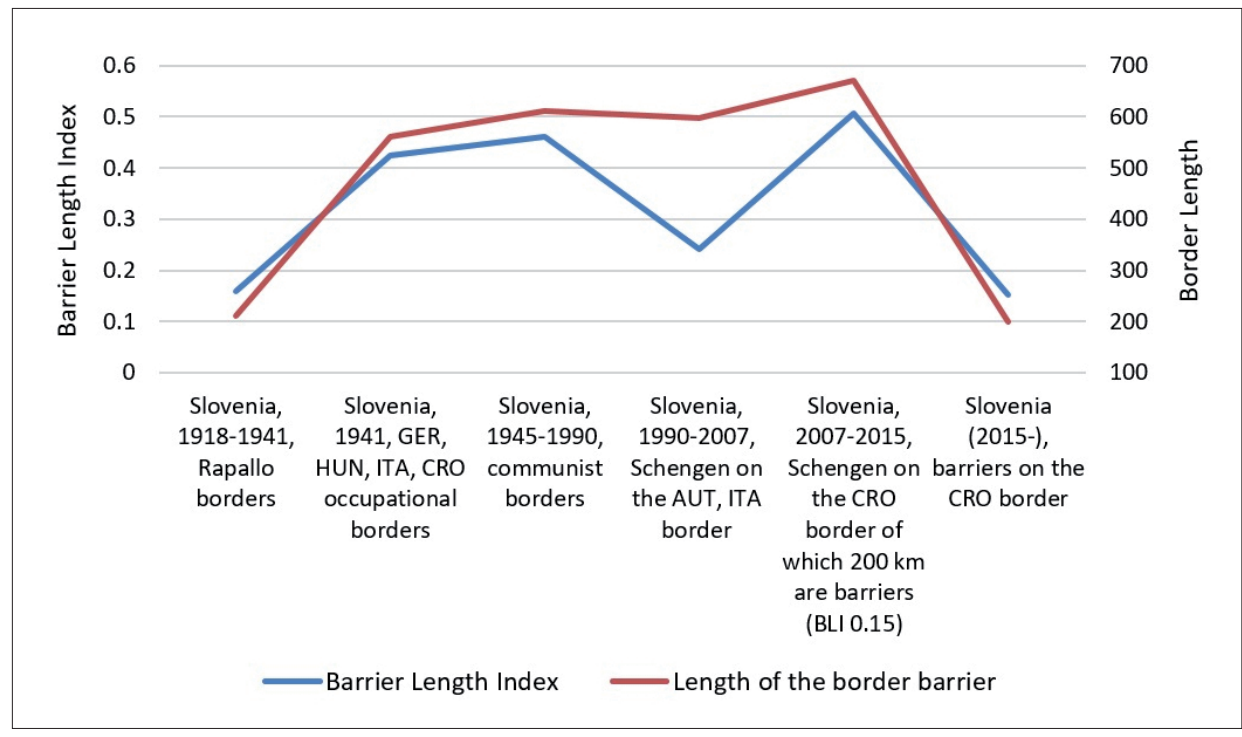

Fig. 6: Changes of the BLI due to political changes in Slovenia in the last century Source: authors' calculations 
The new method was first used to analyse barriers at the local level, focusing on privately-owned parcels. Since these are plots of land with known owners, they reflect the physical, social and historic dimensions of geographic regions. Here we have presented examples from different regions on the example of Slovenia. Slovenia makes a good example because it includes the Alps, the Mediterranean, the Pannonian and the Dinaric regions. The calculated parcel BLIs were quite high, ranging from 0.50 to 1.00 , with the lowest values recorded in the Mediterranean regions.

We then extended the analysis across geographic scales to more publicly controlled neighbourhoods. We presented data for the street level and the control group at the onehectare level. Differences between geographic regions are also evident at this level, with BLI lowest in the Dinaric region and highest in the Pannonian region. We observe the influence of globalisation, however, the modern construction of parcel fences follows traditional patterns. Analysis at the level of one-hectare plots from randomly selected areas around the world shows that plot boundaries are marked everywhere. However, their closedness differs according to historical development and perceptions of ownership; communal and public lands usually have no fences.

Further, the method has been applied to human and physical regions, states, and transnational communities. The countries was analysed more thoroughly since the most data are available at this level. It is no doubt barriers have something in common at all spatial levels. We assume that several underlying processes influence the continuous barriering of the parcels, territories and countries. Being socio-technical structures or devices (Pallister-Wilkins, 2016) that inhibit or promote human interaction and mobility, the border barriers reflect social relations. Therefore, physical structures in the landscape are influenced also by social environments and contexts.

One way to approach the complex institution of barriers (Sassen, 2008) is to understand them as social structures. A natural limitation of the index is that it does not define the absolute characteristics of the spatial entities it distinguishes. Therefore, we introduced a denominator to compare spatial units at all spatial levels according to social aspects. Since family structures with their various types are one of the basic institutions of society, they are a common basis for research in agriculture (family farms), medicine, statistics, urban planning and also for border studies. Borderlands are formed through cross-border regionalisation processes at various levels, including everyday economic, social, familial, and cultural practices (Kolossov and Scott, 2013). We use it here because it provides geographical information as a level between the individual and society (Guo et al., 2021). Family types link the parcel level, which is characterised by private property (of a group of people, e.g. a 'family'), and the regional or national level, which is characterised by shared governance and defined by shared values expressed by the predominant family type. At the same time, the term provides insight into the relationships between society and space, which are reflected in borders and border barriers.

Family structures are extremely persistent, lasting, stable (Masso et al., 2021) and they affect other socioeconomic structures, including separation between poor and wealthy neighbourhoods (Vallet and Jones, 2012). Medieval family structures even influenced European regional disparities, causing the states to become isolated by closing borders. According to Todd (1987): "Every anthropological system lives out its own political dreams, keeping interaction with its neighbours to the minimum possible" (1987, p. 25). The neighbourhoods are limited by boundaries that are established by social or political agents or agencies, to distinguish between national, ethnic, religious, linguistic, legal, or security differences (Haselberger, 2014). "[T]he oldest political borders in Europe are only a few hundred years old, and most were established more recently than that", which is linked to advances in cartography that allowed fixed borders and territories to be represented (Jones, 2012, p. 70).

Barriers are a physical representation of invisible discontinuities, where the social system reveals its underlying logic: family structures define the ideological systems (Todd, 1985) and development level (Duranton, Rodriguez-Pose and Sandall, 2007), including wealth and inequality, and they influence (self)enclosure at the regional and local scales. Therefore, many barriers are located on economic or social discontinuity lines (Ribeiro, Burnet and Torkar, 2013).

The relation between border barriers and family types confirms Reece Jones's hypothesis (2012, p. 70) that in most instances the barriers are the result of the "internal politics of the state that builds them" (see Fig. 7). Similarly, Rosière and Jones (2012) argue that, although countries try to justify building walls with smuggling, migration, and terrorism, these barriers are mostly connected with managing immigration flows. They are an internal affair and build a sense of security and identity. An example of this is the construction of the Israeli West Bank wall (Pullan, 2013), which was built for reasons of "demography", with the International Court of Justice declaring it illegal in 2004. Along similar lines, the Swiss government has rejected the idea of building a fence along its border with Italy because of no clear legal basis to authorise its construction (Cabinet..., 2016).

To illustrate this point, we use the typology of Todd (1985), who introduced two opposites - liberal/authoritarian and equal/unequal - to capture the dimensions of liberty and equality and introduced family types. These dimensions also relate to the balance between security and freedom (Heiskanen, 2016) that are reflected in border issues (Fig. 7). Because of their fundamental basis they can be related to place-based realities, such as property (parcel level) and territory (country level) as illustrated in this article. We ranked countries in terms of the average BLI and family type (modern data of Todd's 1985 typology were taken from Rijpma and Carmichael, 2016).

The highest average BLI (0.35) is typical of countries with predominantly endogamous community types. Their borders are barriered and closed: they have a high average BPI (1.06), the highest average BCI (0.34). This type is found in Asian and Middle Eastern countries. A similarly high average BLI (0.30) is typical in countries with predominantly exogamous communitarian types, which have a low BPI (0.29), and very low BCI (0.03). This type is characterised by egalitarian societies that tend to protect themselves more against the "unequal" and "others" (Duranton et al., 2007). This family type is found in European countries with border barriers. The African type with barriers predominates in Botswana and South Africa, characterised by unstable households, generally strong prohibitions on consanguinity, and polygyny. Their BLI is 0.13 , their BCI 0.14 , and their BPI is very high (1.12). The egalitarian nuclear type is characterised by low BLI $(0.09)$ and BPI (0.12), and a moderate BCI (0.22). This type with liberal intergenerational relationships predominates in countries with border barriers, such as Greece, Hungary, Spain, and the 
US. The authoritarian type has low BLI (0.08) and BPI (0.06), and thin borders (BCI 0.06). In these "strong bureaucratic" countries (Todd, 1987, p. 148), border barriers can be found in Austria and North Korea, while barrier-free countries include those in the Schengen Area, and naturally isolated Japan.

The fluid and liberal anomic type with a low BLI (0.08) is found in barrier-free countries, such as Burma, the Philippines, Indonesia, Laos, Madagascar, Cambodia, and Malaysia, and in South America. Barriers are not present in rare countries with an asymmetrical communitarian system (an example is southern India), and in countries with the prevailing absolute nuclear type (English-speaking countries, the Netherlands, and Denmark).

A third (9) of the analysed 25 countries has BLI and BCI above 0.25. Seven countries have BLI and BCI below 0.10. The values of BLI are upward-limited (Fig. 8). The maximal value can be estimated based on the BCI by the equation: $\mathrm{BLI}=-0.197 \ln (\mathrm{BCI})+0.1941\left(\mathrm{R}^{2}=0.9843\right)$.

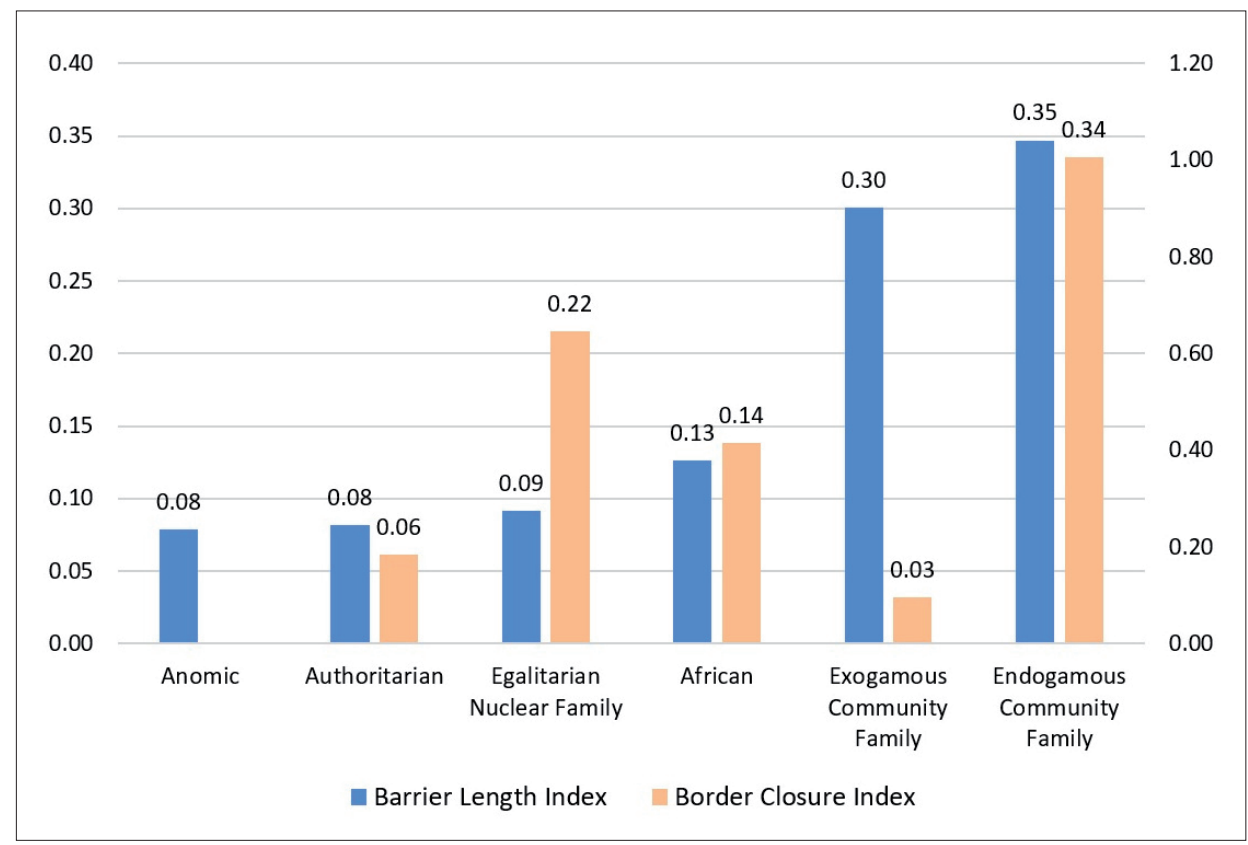

Fig. 7: The BLI and BCI by family types as defined by Todd (1985) in the countries examined Source: authors' calculations

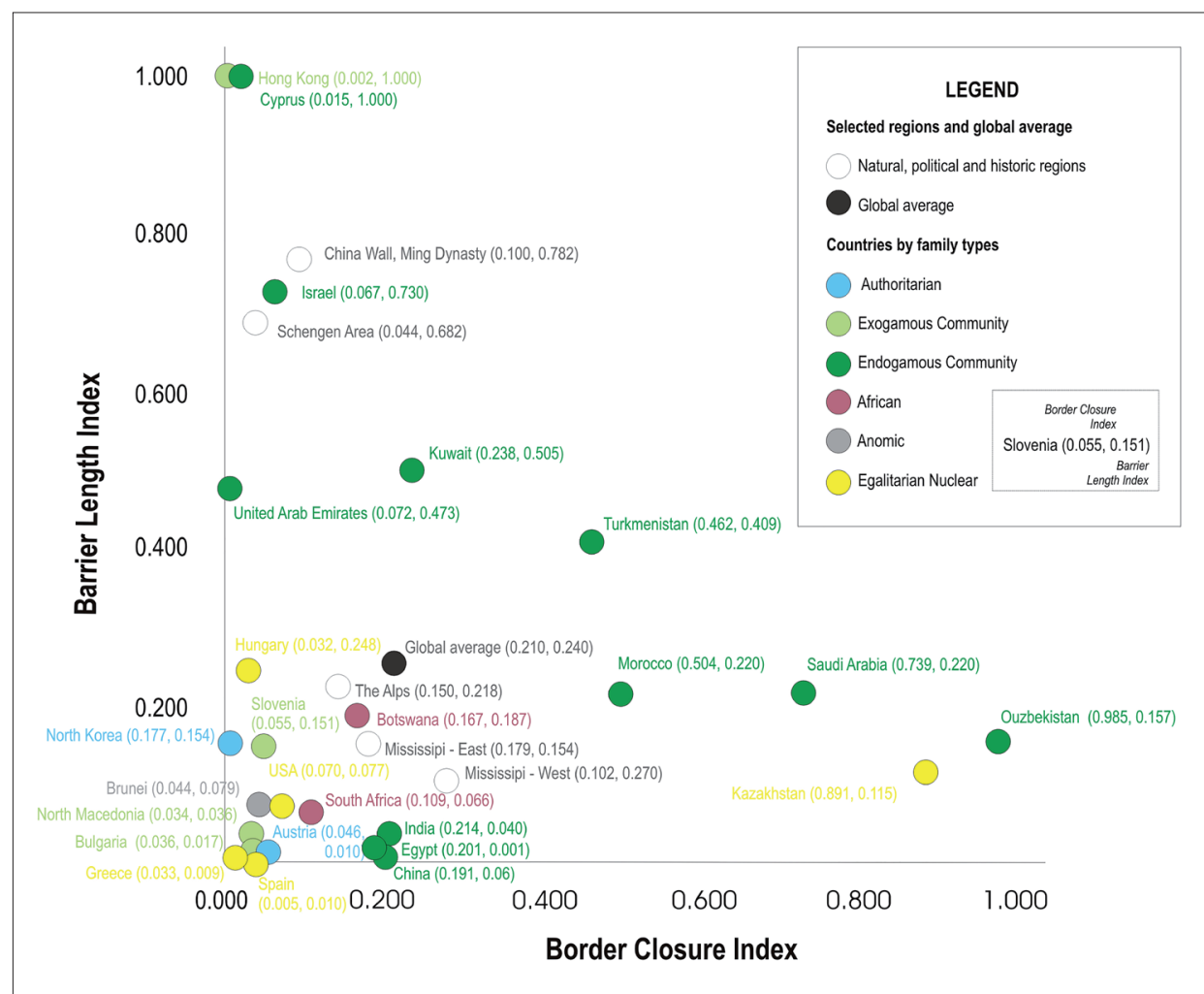

Fig. 8: Barrier Length Index (BLI) in relation to the Border Closure Index (BCI) by country and selected other areas, and the predominant family type (note: for the Ming Dynasty we used a theoretical value of BCI (0.1) Source: authors' calculations 


\subsection{Some implications of the Barrier Index}

The Barrier Index makes it possible to analyse entities enclosed by borders and to compare them in terms of physical spatial features, such as fences and border barriers, as shown in this paper. The data to calculate the Barrier Index and the sub-indices can be easily obtained by field work and remote sensing techniques, such as Google Street View. The data can also be extracted using remote sensing methods, which extends the applicability to areas that are not directly accessible. This also expands the possibilities to reproduce the study.

Although the presented index refers to the physical environment, it is related to the social background, as stated in the previous section. Using the examples of historical regions, we argue that the index can also be used to represent other geographical elements of the landscape, its functions, history, geography (e.g. related to land use) and culture. Its multiple uses include, for example, the analysis of 'barriers' in terms of cultural differences, such as language groups (represented by the predominant language or the number of languages spoken in a spatial unit, such as a household or a country), economic regions (and their invisible barriers, represented by economic inequalities, the origin and location of investments), and historical regions with an impact on the contemporary landscape.

All this implies that the border barriers also are related to expressing identity (Foucher, 2007). At all levels, they physically characterise an area of identity and serve as individual and social expressions or identity symbols. They are largely created to preserve or protect this identity against external influences. The reasons for the increasing trend (Vallet and David, 2012) of this type of "self-protection" are mostly internal; this is suggested by the stable differences in the social structures, reflected in the proposed relation between the Barrier Index and border openness.

We used the stable features of family types and inheritance systems to analyse if different social properties conditioned the Barrier Index. When related to the proposed Barrier Index, this feature made possible a structural and spatial analysis from the scale of an individual and family to the scale of a country. We found that the concept partially explains the general picture of current border barriers and closure. The index provides insight into the background of certain spatial processes and makes it possible to examine their past, present, and future.

Although we observe the (re)appearance of walls and barriers as instruments for the protection of state sovereignty (Vallet and Jones, 2012), the question of whether border barriers in fact increase security remains unresolved (Vallet, 2018). Yet, it is still a topical issue, especially considering migrants and the Covid-19 crisis, when many countries have been closing and reopening their borders (Böhm, 2021) (Fig. 9).

Border barriers can be considered largely ineffective and indeed destructive for the space that surrounds them, as presented by Dear (2013) for the US-Mexico border. But they are indirectly connected with the openness and peacefulness of spatial entities, from regions to countries, because in border regions cross-border conflicts are inversely proportional to the level of cross-border cooperation.

Limitation of the study might be the availability of data. The data of parcel shapes, usually extracted from the land cadaster data, are not publicly available in every country. The data for other spatial units, including countries, are scattered in different literatures.
One limitation can be seen in the fact that only the land border is considered as a basic prerequisite for ensuring comparability across scales. This can be seen in the case of North and South Korea. Because of this, the situation regarding border barriers, as reflected by the Barrier Index in North Korea looks "better" than in South Korea. Further, the analysis of the Index on the local level is limited to urban areas with urban land use. Large parcels in rural areas are usually not "locked" by fences or other barriers.

The index and its subtypes focus on the spatial characteristics of borders, defined by barriers. As the barriers are erected on land, the index does not describe the properties of the borders related to air or water. Here, only land border crossings were used to calculate border openness. The index could be updated with sea and air border crossings to better reflect the effect of barriers on island countries, for example.

A specific challenge is related to the analysis of Barrier Index between neighboring regions in a country. Since these kinds of borders are not defined by formal barriers, the index could be updated with data on transport, economic factors and the influence of other geographical factors. In this way it would add to understanding of the landscape.

Similarly, it is difficult to analyse natural and historical regions without clearly defined borders. In this regard, comparative studies of similar entities are only possible. But on the other hand, the index allows to present changes in a region through time, which is an added value to better understanding of geographical processes in modern landscapes. As barriers are a becoming an important visual element of the landscape, the Index makes it possible to identify visual differences between the landscapes by the architectural properties of barriers in different regions and countries.

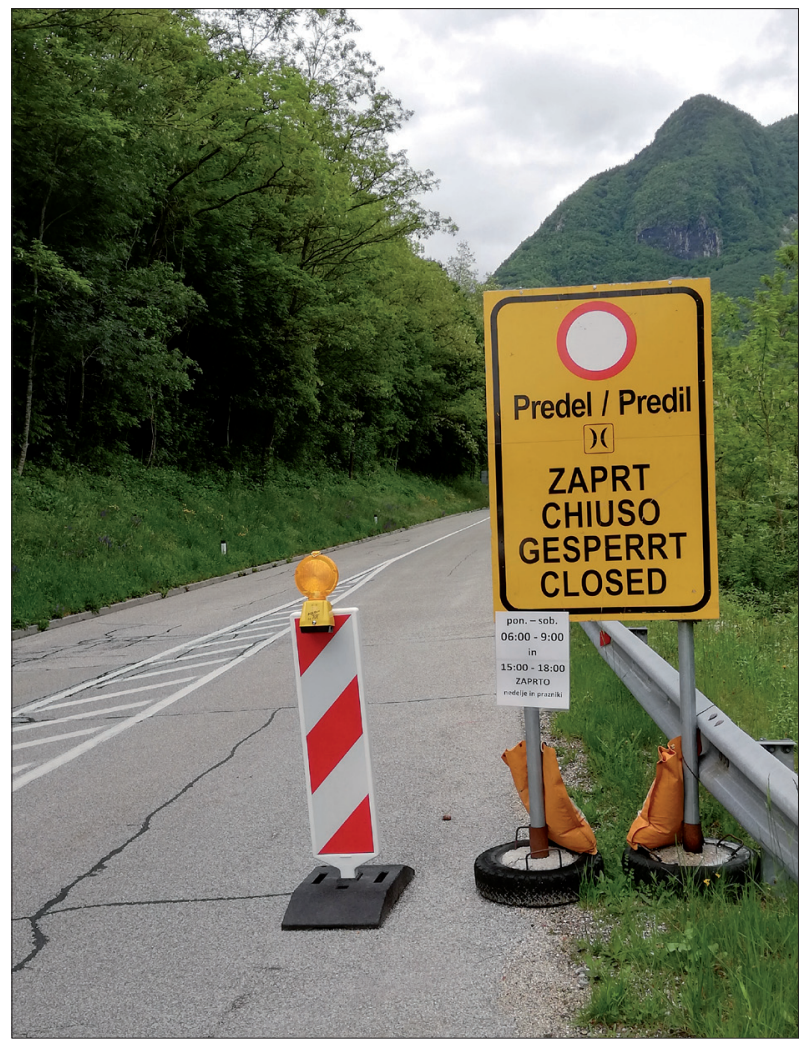

Fig. 9: Several borders were physically closed during the COVID-19 pandemics

Source: B. Komac 


\section{Conclusions and policy implications}

This article proposes an indicator for the analysis of the closedness of borders. The Barrier Index was used to analyse units enclosed by borders and to compare them in terms of spatial characteristics, function, history, geography (e.g. in relation to land use), and culture. It allows for temporal and spatial comparison of barriered borders regardless of size, from the level of parcels, settlements and to countries.

The Barrier Index has been further developed into four subtypes, namely the Barrier Length Index (BLI), which defines the proportion of the perimeter of a unit relative to the total perimeter on which a barrier could be erected. It is expressed in absolute values as $\mathrm{m} / \mathrm{m}$ or in relative values as a percentage of a parcel's fenced perimeter. The Barrier Area Index (BAI) shows the length of a fence per area of the spatial unit enclosed by that fence $\left(\mathrm{m} / \mathrm{m}^{2}\right)$. For spatial units with known population the Barrier Population Index (BPI) can be calculated, which compares the Barrier Length Index to the population (in our case, per 10,000 people). The Barrier Closure Index (BCI) shows the ratio of barrier length in 1,000 km divided by the number of barrier openings or crossings and defines barriers as "open" or "closed".

The Barrier Index was calculated for scaling spatial levels, from the level of parcel to physical-geographic units, to show its potential use, although it was developed at the country level with the most available data. We compared the values of the Barrier Index for 25 countries from different continents and with different social and physical contexts. The BLI is highest in the Middle East (average value: 0.40), followed by Asia (0.28), Africa (0.13), the Americas (0.08) and Europe (0.07), while the BCI is highest in Asian countries (0.40), and followed by the Middle East (0.23), Africa (0.14), the Americas (0.07) and Europe (0.04). It is interesting to note that the maximum values of BLI and BCI are connected by inverse relationship.

The proposed index allows spatial and temporal comparison of various barriers at the scale of parcels, settlements and their parts, regions and states, as well as other geographical units. The BLI for the Schengen area was estimated to be 0.68 , for historical China 0.78, while in Slovenia it varied from a minimum of 0.15 (1918 and 2015) to a maximum of 0.50 (2007-2015). Natural regions such as the Alps (0.22) and the Mississippi region (0.15) have low values for the BLI.

The concept we present links all types and categories of borderlines across scales into a single measure. Because these are measurable values, the predominant character of the units' physical "openness" or "closedness" can be determined regardless of their size. It thus addresses the influence of the barriers on different aspects of the society. The article brings a selection of examples at different spatial units to present the method. The discussion relates the results to the societal processes to present influencing factors that work across spatial scales. We argue that the Border Index at different spatial levels can be partly explained by underlying structures of the society, expressed, for example, by family types, that are quite stable throughout history.

The index could help identify relationships and similarities between barriers at local and state levels. Policy makers can more easily assess the impact of boundary closures at the local level and feed the results into management at higher spatial levels. The Index can provide data to monitor the status of the border and its visible or invisible barriers within territorial units. Since the degree of openness/closure of spatial units at different levels is linked to underlying social mechanisms (Dołzbłasz, 2015), it is possible that countries with more closed boundaries at the parcel level are also more closed within their borders.

From a visual perspective, the Barrier Index adds value to landscape management. It provides policy makers with a comprehensive view of the openness of the landscape that could determine the future development of private and common lands.

Further work will explore the implications of boundary openness. This includes, but is not limited to the flow through the boundary through crossings such as bridges and tunnels. This would provide decision makers at various levels with a good tool for planning and advocating for appropriate land use policies.

As higher values of the index could indicate lower levels of safety in a selected area, comparing index values between settlements and regions could help policy makers to define areas where people feel more 'unsafe'. In a modern society characterised by individualisation, economic and social inequality, safety is an important factor in the quality of life. The index could contribute to a better quality of life in the future. Trust in the state, the community, the neighbours is reflected in the degree of openness of borders - defined also by their physical bordering. One such example is the open borders between Schengen countries within the EU. In case of emergencies or mistrust in the successful functioning of the neighbours (e.g. pandemic, migration), the establishment of a border regime increases the BCI. In this way, the Index can be used to observe present and predict future developments of border areas - "space and borders are closely intertwined" (Peńa, 2021).

\section{Acknowledgement}

This work was supported by the Slovenian Research Agency under Grant "Geography of Slovenia" No P6-0101.

\section{References:}

ADEY, P. (2004): Surveillance at the airport: surveilling mobility/mobilising surveillance. Environment and Planning A, 36: 1365-1380.

AGNEW, J. A. (1994): The territorial trap: the geographical assumptions of international relations theory. Review of International Political Economy 1: 53-80.

ALM, L. R., BURKHART, R. E. (2013): Bridges and Barriers: The Lake Superior Borderlands. Journal of Borderlands Studies 28(1): 47-60.

ALTMAN, I., WOHLWILL, J. F. (1977): Human behavior and environment. New York, Springer.

AMOORE, L. (2006): Biometric borders: Governing mobilities in the war on terror. Political Geography 25: 336-351.

BALLIF, F., ROSIÈRE, S. (2009): Le défi des «teichopolitiques». Analyser la fermeture contemporaine des territoires. LEspace geographique, 38(3): 193-206.

BIGO, D. (2011): Freedom and speed in enlarged borderzones. In: Squire, V. [ed.]: The Contested Politics of Mobility: Borderzones and Irregularity (pp. 31-50). Abingdon, Routledge.

BÖHM, H. (2021): The influence of the Covid-19 pandemic on Czech-Polish cross-border cooperation: From debordering to re-bordering? Moravian Geographical Reports, 29(2): 137-148. 
BROWN, W. (2010): Walled States: Waning sovereignty. New York, MIT Press.

Cabinet says Ticino border fence not needed [online]. [cit. 11.05.2021]. Available at: https://www.swissinfo.ch/ eng/immigration_cabinet-says-ticino-border-fence-notneeded $/ 42600970$

CASEY, E. S., WATKINIS, M. M. (2014): Up against the wall: Re-imagining the U.S.-Mexico border. Austin, University of Texas Press.

CLARK, A. N. (1998): Dictionary of geography. New York, Penguin.

DEAR, M. (2013): Why walls won't work. Oxford, Oxford University Press.

DOŁZBŁASZ, S. (2015): Symmetry or asymmetry? Crossborder openness of service providers in Polish-Czech and Polish-German border towns. Moravian Geographical Reports, 23(1): 2-12.

DOMÍNGUEZ-MUJICA， J., DÍAZ-HERNANDEZ， R., PARRENO-CASTELLANO, J. (2016): The Canary Islands' "Maritime Wall": Migration pressure, security measures and economic crisis in the Mid-Atlantic. In: Vallet, E. [ed.]: Borders, fences and walls: State of insecurity? (pp. 27-50). London. / New York, Routledge.

DONNAN, H., WILSON, T. W. (1999): Borders: Frontiers of identity, nation and state. Oxford/New York, Routledge.

DURANTON, G., RODRÍGUEZ-POSE, A., SANDALL, R (2007): Family types and the persistence of regional disparities in Europe. Bruges European Economic Research Papers 10.

ELDEN, S. (2013): The birth of territory. Chicago, Chicago University Press.

FOŠKI, M. (2019): Using the parcel shape index to determine arable land division types. Acta geographica Slovenica 59(1): 83-101.

FOUCAULT, M. (2009): Security, territory, population: Lectures at the Collège de France 1977-1978. New York, Macmillan.

FOUCHER, M. (2007): L'Obsession des frontiers. Paris, Perrin.

FOUCHER, M. (2011): La Bataille des cartes. Analyse critique des visions du monde. Paris, François Bourin.

GAMS, I. (2001): O Afganistancih in drugih gorjancih. Geografski vestnik 73(2): 33-41.

Geodetska uprava Republike Slovenije. Portal Prostor [online]. [cit. 26.01.2020]. Accessible at: http://prostor3. gov.si/javni/login.jsp?jezik $=\mathrm{sl}$

GOLUNOV, S. (2014): Border fences in the globalizing World: Beyond traditional geopolitics and post-positivist approaches. In: Vallet, E. [ed.]: Borders, fences and walls: State of insecurity? (pp. 117-129). London / New York, Routledge.

Google Earth Street View. US Department of State Geographer, 2009.

GUO, X., YANG, Y., CHENG, Z., WU, Q., CHENJING, L., LO, T., CHEN, F. (2021): Spatial social interaction: An explanatory framework of urban space vitality and its preliminary verification. Cities, 103487; in press.

HASELBERGER, B. (2014): Decoding borders. Appreciating border impacts on space and people. Planning Theory and Practice 15(4): 505-526.
HEISKANEN, M. (2016): Border games: From duel to Russian roulette at the border. In: Vallet, E. [ed.]: Borders, fences and walls: State of insecurity? (pp. 67-83). London/New York, Routledge.

HEYMAN, J. McC. (2008): Constructing a virtual wall: Race and citizenship in U.S.-Mexico border policing. Journal of the Southwest 50(3): 305-333.

IRWIN， E. G., BOCKSTAEL， N.E. (2004): Land use externalities, open space preservation, and urban sprawl. Regional Science and Urban Economics 34(6): 705-725.

JIRÓN, P. (2010): Mobile borders in urban daily mobility practices in Santiago de Chile. International Political Sociology 4(1): 66-79.

JOHNSON, C., JONES, R., PAASI, A., AMOORE, L., MOUNTZ, A., SALTER, M., RUMFORD, C. (2011): Interventions on rethinking 'the border' in border studies. Political Geography 30(2): 61-69.

JONES, R. (2012): Border walls: Security and the War on Terror in the United States, India, and Israel. London / New York, Barnes and Noble.

KLADNIK, D., LOVRENČAK, F., OROŽEN ADAMIČ, M. [eds.] (2005): Geografski terminološki slovar. Ljubljana, Založba ZRC.

KOLOSSOV, V. (2005): Border studies: Changing perspectives and theoretical approaches. Geopolitics 10(4): 606-632.

KOLOSSOV, V., SCOTT, J. (2013): Modelling and benchmarking of borders. Selected conceptual issues in border studies. Questions conceptuelles dans les recherches sur les frontiers. Belgeo 1/2013.

KOMAC, B., KUŠAR, D. (2017): Sledi ruralne dediščine v urbani pokrajini. Geografski vestnik 89(1): 79-97.

KONRAD, V. (2016): Borders, bordered lands and borderlands: Geographical states of insecurity between Canada and the United States and the impacts of security primacy. In: Vallet, E. [ed.]: Borders, fences and walls: State of insecurity? (pp. 85-102). London / New York, Routledge.

KUŠAR, D., KOMAC, B. (2019): Ograje v urbani podobi Slovenije. Geografski vestnik 91(1).

LOCCHI, M. C. (2016): The Mediterranean Sea as a European border: Trans-Mediterranean migration, forced return and violation of fundamental rights. In: Vallet, E. [ed.]: Borders, fences and walls: State of insecurity? (pp. 1126). London/New York, Routledge.

MASSO, A., SILM, S., PUURA, A. (2021): Identifying relationships between personal social networks and spatial mobility: A study using smartphone tracing and related surveys. Social Networks 68: 306-317.

MEDZINI, A. (2016): Life on the border: The impact of the separation barrier on the residents of the Barta'a enclave demilitarized zone. Journal of Borderlands Studies 31(4): 401-425.

MINONDO, A. (2007): The disappearance of the border barrier in some European Union countries' bilateral trade. Applied Economics 39(1): 119-124.

MULTIPLICITY (2005): Borders: the other side of globalisation. In: McQuire, S., Papastergiadis, N. [eds.]: Empires, ruins + networks: The transcultural agenda in art. Melbourne, Melbourne University Press. 
NEWMAN, D. (2003): On borders and power: A theoretical framework. Journal of Borderlands Studies 18: 13-25.

NEWMAN, D. (2006): Borders and bordering. European Journal of Social Theory 9(2): 171-186.

NIJKAMP, P., RIETVELD, P. (1989): Barriers to communication: Conceptual issues. Paper presented at the NECTAR meeting on Barriers to communication. Zurich.

PALLISTER-WILKINS, P. (2016): How walls do work: Security barriers as devices of interruption and data capture. Security Dialogue 47(2): 151-164.

PARKER, N., VAUGHAN-WILLIAMS, N. (2009): Lines in the sand? Towards an agenda for critical border studies. Geopolitics 14(3): 582-587.

PEŃA, S. (2021): From Territoriality to Borderscapes: The Conceptualisation of Space in Border Studies. Geopolitics, 1-29.

PERKO, D., CIGLIČ, R., ZORN, M. (2019): The Geography of Slovenia: Small but diverse. Dordrecht, Springer.

PETEK, F., URBANC, M. (2007): Skupna zemljišča v Sloveniji. Geografski vestnik 79(2): 41-62.

POUNDS, N. J. G. (1972): Political geography. New York, McGraw Hill.

PULLAN, W. (2013): Conflict's tools. Borders, boundaries, and mobility in Jerusalem's spatial structures. Mobilities 8(1): $125-147$.

REPE, B. (2018): Italijansko-jugoslovanska meja po drugi svetovni vojni: prehodi meje, turizem, nakupovanje, tihotapljenje. Nečakov zbornik: procesi, teme in dogodki iz 19. in 20. stoletja, (pp. 679-688). Historia 25. Ljubljana, Univerza v Ljubljani.

REVZINA, Y. (2018): Architect as geographer. The renaissance architectural theory on fortification and territory. $5^{\text {th }}$ SGEM International Multidisciplinary Scientific Conferences on Social Sciences and Arts SGEM2018.

RIBEIRO, D., BURNET, J. E., TORKAR, G. (2013): Four windows on Borderlands: Dimensions of place defined by land cover change data from historical maps. Acta geographica Slovenica 53(2): 317-342.

RIJPMA, A., CARMICHAEL, S. G. (2016): Testing Todd and Matching Murdock: Global Data on Historical Family Characteristics. Economic History of Developing Regions 31(1): 10-46.

ROCHE, J. J. (2016): Walls and borders in a globalized World: The paradoxical revenge of territorialization. In: Vallet, E. [ed.]: Borders, fences and walls: State of insecurity? (pp. 105-115). London / New York, Routledge.
ROSIÈRE, S., JONES, R. (2012): Teichopolitics: Reconsidering globalisation through the role of walls and fences. Geopolitics 17(1): 217-234.

SASSEN, S. (2008): Territory, authority, rights: From Medieval to Global assemblages. New York, Princeton University Press.

SILVEY, R., OLSON, E. A., TRUELOVE, Y. (2007): The politics of border crossing. In: Cox, K. R., Low, M., Robinson, J. [eds.]: The SAGE Handbook of Political Geography. Thousand Oaks, Sage Publishing.

The World Factbook. Washington: Central Intelligence Agency, 2019 [online]. [cit. 28.02.2020]. Available at: https://www.cia.gov/library/publications/the-worldfactbook

TODD, E. (1985): The Explanation of Ideology: Family structures and social systems. Oxford, Blackwell Publishing.

TODD, E. (1987): The causes of progress. Culture, authority and change. In: Laslett, P., Anderson, M., Wrightson, K. [eds.]: Family sexuality and social relations in past times. London, Blackwell Publishing.

VALLET, E. (2018): Borders, fences and walls: State of insecurity? (pp. 1-7). London/New York, Routledge.

VALLET, E., DAVID, C. P. (2012): Introduction: The (re) building of the wall in international relations. Journal of Borderland Studies 27(2): 111-119.

VAN GEENHUIZEN, M., RIETVELD, P. (2002): Land-borders and sea-borders: An exploration of differences in border region development. Journal of Borderlands Studies 17(2): 63-77.

VILA P. [ed.] (2003): Ethnography at the border. Cultural studies of the Americas 13. Minneapolis, University of Minessota Press.

VITRUVIUS, P. (2009): O arhitekturi. Ljubljana

WARF, B. (2010): Encyclopedia of Geography 1. Thousand Oaks, Sage Publications.

WENTZ, E. (2000): A shape definition for geographic applications based on edge, elongation, and perforation. Geographical Analysis 32(2): 95-112.

WILLS, E. R. (2016): Constructing a "Wall": Discursive fields, social movements, and the politics of the (Wall/Barrier/ Fence). Journal of Borderlands Studies 31(3): 305-318.

\section{Please cite this article as:}

KUŠAR, D., KOMAC, B. (2021): Barriers everyone: A new method for multiscale analysis of barriers using the Barrier Index. Moravian Geographical Reports, 29(4): 292-305. doi: https://doi.org/10.2478/mgr-2021-0021 